Nig. J. Biotech. Vol. 38 (1) : 109-119 (June 2021)

ISSN: 01891731

Available online at

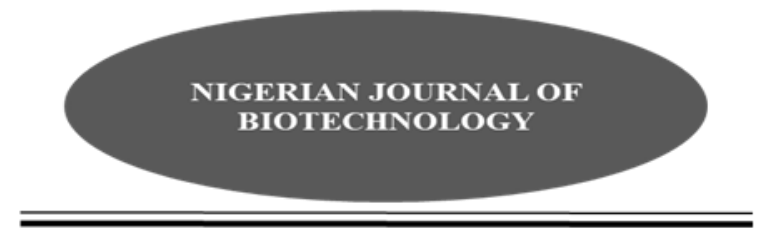

http://www.ajol.info/index.php/njb/index

and www.biotechsocietynigeria.org

DOI: https://dx.doi.org/10.4314/njb.v38i1.13

\title{
Morphological diversity in growth characteristics of Jatropha curcas l. accessions from South- West Nigeria
}

\author{
Adebusuyi, G.A.*, Oyedeji, O.F., Alaje V.I., Sowunmi I.L. and Dunmade, Y. A. \\ Forestry Research Institute of Nigeria, P.M.B. 5054, Jericho Forest Hill, Ibadan, Nigeria.
}

\begin{abstract}
Jatropha curcas is a multi-purpose tree with significant economic importance that has not been fully exploited due to lack of adequate breeding programme in Nigeria. Consequently upon this, 31 accessions collected from 4 states in Southwestern Nigeria were assessed for their morphological diversity in order to establish this as a bed rock for further breeding programmes. Data were collected on plant height, numbers of leaves and collar diameter; these were subjected to analysis of variance, principal component analysis and cluster analysis using Minitab version 17. The results showed significant differences ( $\leq 0.05$ ) among the 31 accessions assessed. Principal component analysis indicated that the first three axes contributed $97.8 \%$ of the total variation observed. The first axis accounted for $68 \%$ of the total variation while the second and third axes accounted for $24.7 \%$ and $5.1 \%$, respectively, of the total variation recorded. Cluster analysis as well as the dendrogram revealed three distinct clusters of genetic similarities and differences. High genetic similarities were observed among accessions collected from the different states whereas some accessions collected from similar regions had low genetic similarities. Cluster 1 consisted of 21 genotypes with their characters falli ng below the grand mean. Cluster 2 had nine genotypes, they produced the highest values for all the characters assessed. Cluster 3 with only one genotype has its values below the ground mean. Members of cluster 2 have proven to be superior. The existence of morphological diversity offers potential for selection among the accessions in the breeding of J. curcas from southwestern Nigeria.
\end{abstract}

Keywords: diversity, clustering, accessions, Jatropha curcas, characters

*Corresponding Author's e mail:- goldenscopes@yahoo.com Phone No; 08038276947

\section{Introduction}

Jatropha curcas belongs to the family of Euphorbiaceae. It is also known as a physic nut. It is a tree with economic importance and many uses. It grows well in arid and semi-arid regions and can be used to prevent soil erosion (Nahar and Ozores-Hampton, 2011). J. curcas grows well in areas with varying rainfall distribution and so it can withstand drought. It is easy to propagate through seeds, requires minimum silvicultural practices and can produce seeds for about 50 years. Biodiesel, which is an alternative diesel fuel, can be produced from natural renewable sources such as vegetable oils and fats from animals (Sukarin et al., 1987; Kumar and Sharma 2008; Sujatha et al., 2008; Sharama et al., 2011). Due to the $30 \%$ oil composition of its nut and with the increasing interest in the production of biodiesel, J. curcas is now considered as one of the promising sources of biodiesel (Shabanimofrad et al., 2011; Cai et al., 2010; Divakara et al., 2010; Gohil and Pandya 2009; Achten et al., 2008; Ganesh Ram et al., 2008). Reports have shown that the maximum oil content for J. curcas seeds has been close to $47 \%$ 
whereas the accepted oil content average is 37 $40 \%$. Thus, J. curcas is seen as a potential plant for future production of biodiesel (Jongschaap, et al., 2007). Apart from its potentials for biodiesel production, J. curcas can also be used for several purposes which include but not limited to saponification of oil in the process of making soap, cleaning, dye for clothes, and organic fertilizer. It is used also in cosmetic manufacturing in many tropical countries (Martinez-Herrera, et al., 2006). J. curcas oil is also used to soften leather and can serve as a lubricant for machines and its parts. Virtually every part of the plant has its own uses which makes it an economically important species (Gubitz, et al., 1999).

Of the many species existing in different parts of the world, $J$. curcas is the commonest species found in Nigeria. In fact, Heller, in 1996 reported that there are about 165-175 known species from the genus Jatropha. There are several names used to describe the plant in different parts of Nigeria. It is known as Binidazugu in Hausa language and Lapalapa in Yoruba language. (Blench, 2007 and Blench, 2003)

The change in color of the capsule from green to yellow is an indication that the seeds are mature. A mature seed generally contains around $20 \%$ saturated fatty acids with $80 \%$ unsaturated fatty acids. It can yield up to $25 \%-40 \%$ oil by weight. The oil basically consists of Linoleic and Oleic acids (Nahar, and Ozores-Hampton, 2011).

Due to the enormous potentials of this species for biodiesel production, several people have started to embark on its plantation (King et al., 2009), but despite this effort, quality planting material is still not available (Ghosh and Singh 2011; Shuit et al., 2010).

Table 1: List of accessions and their source
Knowledge about the degree of genetic diversity between inter and intra populations are needed to gain the first ideas about where to find potentially important genetic material. J. curcas genetic resources have been reported but only limited and scattered knowledge is available on the basic reproductive biology of the species. In addition, little information has been reported on its quantitative genetic variations, such as genetic variance components, heritability, heterosis and effects of interaction between genotypes and environment. Also, one factor of key importance for conducting breeding programs is genetic variability but there is dearth of information available for J. curcas (Franco et al., 2001; Achten et al., 2010; Sun et al., 2008).

In recent years, some researchers have reported genetic variation in the Jatropha populations from India, China, Latin America and Malaysia based on morphological and agronomical characters by using morphological and molecular techniques (Shabanimofrad et al., 2013; Rafii et al., 2012a; Rao et al., 2008; Kaushik et al., 2007; Ginwal et al., 2005). But such information has not been documented for the J. curcas population in Southwestern Nigeria; hence, this study is aimed at investigating the morphological diversity of $J$. curcas accessions and to determine the genetic components of the important characters in the $J$. curcas accessions.

\section{Materials and Methods}

\section{Sources of Planting Materials}

Thirty one (31) accessions of J. curcas seeds were collected from various communities across several states in South-Western Nigeria. In each of the states, plant samples were collected over a distance not less than $20 \mathrm{~m}$ apart in order to avoid collecting multiple seeds from the same parents. From each individual plant, seeds were collected, labelled and placed in plastic bags.

\begin{tabular}{lll}
\hline Genotypes & $\begin{array}{l}\text { Accession } \\
\text { Code }\end{array}$ & Source \\
\hline
\end{tabular}


Adebusuyi et al. / Nig. J. Biotech. Vol. 38 Num. 1 : 109-119 (June 2021)

\begin{tabular}{lll}
\hline G1 & JAT01 & Ibadan, Oyo State \\
G2 & JAT02 & Shaki, Oyo State \\
G3 & JAT03 & Iseyin, Oyo State \\
G4 & JAT04 & Igbo-Ora, Oyo State \\
G5 & JAT05 & Igbeti, Oyo State \\
G6 & JAT06 & Igboho, Oyo state \\
G7 & JAT07 & Sepeteri, Oyo State \\
G8 & JAT08 & Kisi, Oyo State \\
G9 & JAT09 & Eruwa, Oyo state \\
G10 & JAT10 & Ife, Osun State \\
G11 & JAT11 & Osogbo, Osun State. \\
G12 & JAT12 & Ilesha, Osun State. \\
G13 & JAT13 & Ikirun, Osun State. \\
G14 & JAT14 & Ede, Osun State. \\
G15 & JAT15 & Ila, Osun State. \\
G16 & JAT16 & Iwo, Osun State. \\
G17 & JAT17 & Gbongan, Osun State. \\
G18 & JAT18 & Ado-Ekiti, Ekiti State. \\
G19 & JAT19 & Ijero, Ekiti State. \\
G20 & JAT20 & Ikole, Ekiti State. \\
G21 & JAT21 & Oye, Ekiti State. \\
G22 & JAT22 & Emure, Ekiti State. \\
G23 & JAT23 & Ikere-Ekiti, Ekiti State. \\
G24 & JAT24 & Akure, Ondo State. \\
G25 & JAT25 & Okitipupa, Ondo State. \\
G26 & JAT26 & Ikare, Ondo State. \\
G27 & JAT27 & Owo, Ondo State. \\
G28 & JAT28 & Akungba, Ondo State. \\
G29 & JAT29 & Idanre, Ondo State. \\
G30 & JAT30 & Ilara-Mokin, Ondo State. \\
G31 & JAT31 & Oka-Akoko, Ondo State \\
\hline & & \\
\hline
\end{tabular}

\section{Experimental site}

The experiment was carried out at the arboretum of the Forestry Research Institute of Nigeria (FRIN). Headquarters, Jericho, Ibadan. Nigeria is located between $07023^{\prime} 18 " \mathrm{~N}$ to $07023^{\prime} 43^{\prime \prime} \mathrm{N}$ longitude and 03051'20"E to 03051'43"E latitude. The climate of the area is the West African monsoon with distinct dry and wet seasons. The dry season usually starts from November and runs through March. The wet season on the other hand, generally runs through April to October with strong winds and thunderstorms occasionally. Mean annual rainfall falls around $1548.9 \mathrm{~mm}$ approximately, within 90 days. The temperature ranges from $31.9^{\circ} \mathrm{C}$ maximum to $24.2^{\circ} \mathrm{C}$ minimum, while the relative humidity is about $71.9 \%$ daily (FRIN 2015).

\section{Description of the plant material}

Twenty seeds from each of the accessions were sown in germination trays. After which fifteen seedlings from each of the accessions were transplanted into polythene pots, from these ten seedlings were selected in each of the accessions for data collection. The experiment was laid out in a Completely Randomized Design (CRD) with ten replications.

Data for each character were recorded on 310 individual seedlings.

\section{Data collection and analysis}

Data was collected on

- Number of leaves by counting the leaves

- Collar diameter by the use of digital vernier caliper

- Plant height by the use of meter rule 
Data collected were subjected to analysis of variance, principal component analysis as well as cluster analysis using Minitab version $17 . \quad$ Means were separated using fisherman's significant difference $\quad(p \leq 0.05)$.

\section{Results}

The mean square analysis for the thirty one accessions of $J$. curcas revealed significant differences for all the characters, which validated further statistical analysis (Table 2). These results indicate the presence of morphological variation among the accessions studied. The accessions differ significantly at $p \leq 0.05$.

Table 2: Mean square analysis for variation in morphological characters in 31 accessions of $J$. curcas

\begin{tabular}{clllll}
\hline Source of variation & Sum of Squares & Df & CD & NL & PH. \\
& & & & & \\
\hline Accession & 173.254 & 30 & $5.775^{*}$ & $3.241^{*}$ & $37.368^{*}$ \\
Error & 1694.511 & 279 & 6.074 & 1.937 & 30.965 \\
Total & 1867.765 & 309 & & & \\
\hline
\end{tabular}

${ }^{*} \mathrm{p} \leq 0.05, \mathrm{CD}=$ collar diameter, $\mathrm{NL}=$ number of leaves, $\mathrm{Ph}=\mathrm{Plant}$ height

The mean values for different three morphological traits are presented in Table 3. Out of 31 accessions, only 16 accessions (51.61\%) have means above the average collar diameter. Collar diameter ranged from $6.183 \mathrm{~mm}$ to $9.078 \mathrm{~mm}$ with accession JAT23 showing the least collar diameter. Highest collar diameter was accessioned JAT03 $(9.078 \mathrm{~mm})$, followed by JAT26 $(8.599 \mathrm{~mm})$ and JAT12 $(8.596 \mathrm{~mm})$. Highest number of leaves was found in accession 19 (6.135), followed by accession 31 (6.02) and accession 25 (6.01), two of which are from Ondo state (JAT 25 and JAT 31) while JAT 19 was from Ekiti state. The number of leaves ranged from
3.665 (JAT1) to 6.135 (JAT19). Less than $50 \%$ of the accessions (15 accessions) have a high number of leaves. Out of this, 12 accessions had both high collar diameter as well as high number of leaves.

The mean values for plant height ranged from $12.166 \mathrm{~cm}$ (JAT 23) to $20.387 \mathrm{~cm}$ (JAT4). Seventeen accessions (54.839\%) had their means greater than the grand mean. Out of these, accessions (22.58\%) have high collar diameter, number of leaves and plant height.

Table 3: Mean performance of 31 accessions for morphological traits in J. curcas

\begin{tabular}{llll} 
Accessions code & Collar diameter & Number of leaves & Plant height \\
\hline JAT01 & 6.241737 & 3.665 & 14.70158 \\
JAT02 & 7.806684 & 4.855 & 19.45895 \\
JAT03 & 9.077737 & 5.125 & 17.48526 \\
JAT04 & 8.187105 & 4.845 & 20.38789 \\
JAT05 & 8.212053 & 5.155 & 17.98421 \\
JAT06 & 7.005789 & 4.255 & 14.91053 \\
\hline
\end{tabular}


Adebusuyi et al. / Nig. J. Biotech. Vol. 38 Num. 1 : 109-119 (June 2021)

\begin{tabular}{|c|c|c|c|}
\hline JAT07 & 7.228947 & 4.390 & 16.22211 \\
\hline JAT08 & 6.516368 & 4.570 & 14.68421 \\
\hline JAT09 & 8.231474 & 5.495 & 19.97421 \\
\hline JAT10 & 8.136947 & 5.015 & 19.21053 \\
\hline JAT11 & 8.298895 & 4.945 & 19.08 \\
\hline JAT12 & 8.596211 & 5.265 & 18.99632 \\
\hline JAT13 & 7.648895 & 5.085 & 17.10579 \\
\hline JAT14 & 7.401632 & 5.185 & 17.27684 \\
\hline JAT15 & 6.572421 & 4.870 & 16.52053 \\
\hline JAT16 & 7.775842 & 5.470 & 17.48737 \\
\hline JAT17 & 8.305105 & 5.810 & 19.35316 \\
\hline JAT18 & 7.706421 & 5.400 & 15.66842 \\
\hline JAT19 & 8.584211 & 6.135 & 15.16632 \\
\hline JAT20 & 7.450474 & 5.230 & 16.17158 \\
\hline JAT21 & 8.173947 & 5.664 & 17.27737 \\
\hline JAT22 & 6.396368 & 4.905 & 15.46 \\
\hline JAT23 & 6.183737 & 4.735 & 12.16632 \\
\hline JAT24 & 8.147895 & 5.590 & 19.59895 \\
\hline JAT25 & 7.782474 & 6.010 & 17.17474 \\
\hline JAT26 & 8.599316 & 5.970 & 19.54947 \\
\hline JAT27 & 7.373684 & 5.430 & 16.08368 \\
\hline JAT28 & 7.756105 & 5.800 & 15.77632 \\
\hline JAT29 & 7.606368 & 5.915 & 16.52158 \\
\hline JАT30 & 6.897 & 5.190 & 17.21558 \\
\hline JAT31 & 8.388158 & 6.020 & 15.44947 \\
\hline Mean \pm SE & $7.687 \pm 0.136$ & $5.226 \pm 0.102$ & $17.101 \pm 0.347$ \\
\hline
\end{tabular}


Adebusuyi et al. / Nig. J. Biotech. Vol. 38 Num. 1 : 109-119 (June 2021)

\begin{tabular}{llll} 
Fisherman (5\%) & 0.544 & 0.018 & 0.218 \\
CV & 9.89 & 10.89 & 11.3 \\
\hline
\end{tabular}

Table 4 shows the Eigen values, percentage of total variation accounted for and the cumulative percentage of the first three component axes of $J$ curcas . The first three axes contributed $97.8 \%$ of the total variation observed. The first axis accounted for $68 \%$ of the total variation while the second and third axes accounted for $24.7 \%$ and $5.1 \%$ respectively of the total variation seen.

Table 4: Eigen values, percentage of total variation accounted for and cumulative percentage by the first three component axes of $J$. curcas

\begin{tabular}{|c|c|c|c|c|}
\hline $\begin{array}{l}\text { Principal } \\
\text { component }\end{array}$ & Eigen & value & $\begin{array}{l}\text { Percentage variation } \\
\text { accounted for }\end{array}$ & $\begin{array}{l}\text { Cumulative } \\
\text { percentage }\end{array}$ \\
\hline 1 & 2.04 & & 68.00 & 68.00 \\
\hline 2 & 1.74 & & 24.70 & 92.70 \\
\hline 3 & 1.20 & & 05.10 & 97.80 \\
\hline
\end{tabular}

Table 5 shows the three axes and their character loading. According to Hair et al., (1995) usually, Eigen values greater than one are considered significant and component loading greater than 0.30 are also considered to be meaningful. All the characters contributed to the variation in the first principal component axis. The second axis was loaded by plant height and number of leaves while the all three characters made entries and loaded the third axis.

Table 5: The three axes and their character loading

\begin{tabular}{llcc}
\hline Variable & PC1 & PC2 & PC3 \\
\hline Plant height & 0.546 & -0.676 & -0.495 \\
Number of leaves & 0.523 & 0.736 & -0.430 \\
Collar diameter & 0.655 & -0.024 & 0.755 \\
\hline
\end{tabular}

Means characters of three $\mathrm{J}$. curcas groups is as presented in Table 6. Cluster 1 comprises 21 genotypes. All their characters are below the grand mean. Cluster 2 had nine genotypes, they produced the highest values for all the characters assessed. Cluster 3 with only one genotype with its values fallen below the ground mean.

Table 6: Mean of Morphological characters evaluated in three J. curcas clusters

Cluster1

$1,6,8,7,15,22,3,5,13,14,30,16,21$

Variables

,
Cluster2

$2,9,10,11,12,17$

$, 24,26,4$

19.512

17.100

23
Mean and standard deviation

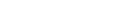

Cluster3

$17.638(1.671)$ 


\begin{tabular}{lclll} 
Number of leaves & 5.213 & $\mathbf{5 . 3 1 0}$ & 5.223 & $5.249(0.053)$ \\
Collar diameter & 7.514 & $\mathbf{8 . 2 5 7}$ & 7.687 & $7.819(0.389)$ \\
Cluster sum of square & 39.483 & 3.476 & 0 & \\
Average distance & $\mathbf{1 . 2 4 2}$ & $\mathbf{0 . 5 9 4}$ & $\mathbf{0}$ & \\
\hline
\end{tabular}

The dendrogram from the Complete Linkage Cluster Analysis is as presented in Figure 1. This illustrated the relationship in terms of similarities and differences among the 31 accessions. At $100 \%$ level of similarity, all the genotypes had formed a single cluster, meaning that all the accessions were distinct at $100 \%$ level of similarity. The dendrogram revealed three distinct clusters of the genotype at $33.33 \%$ similarity level.

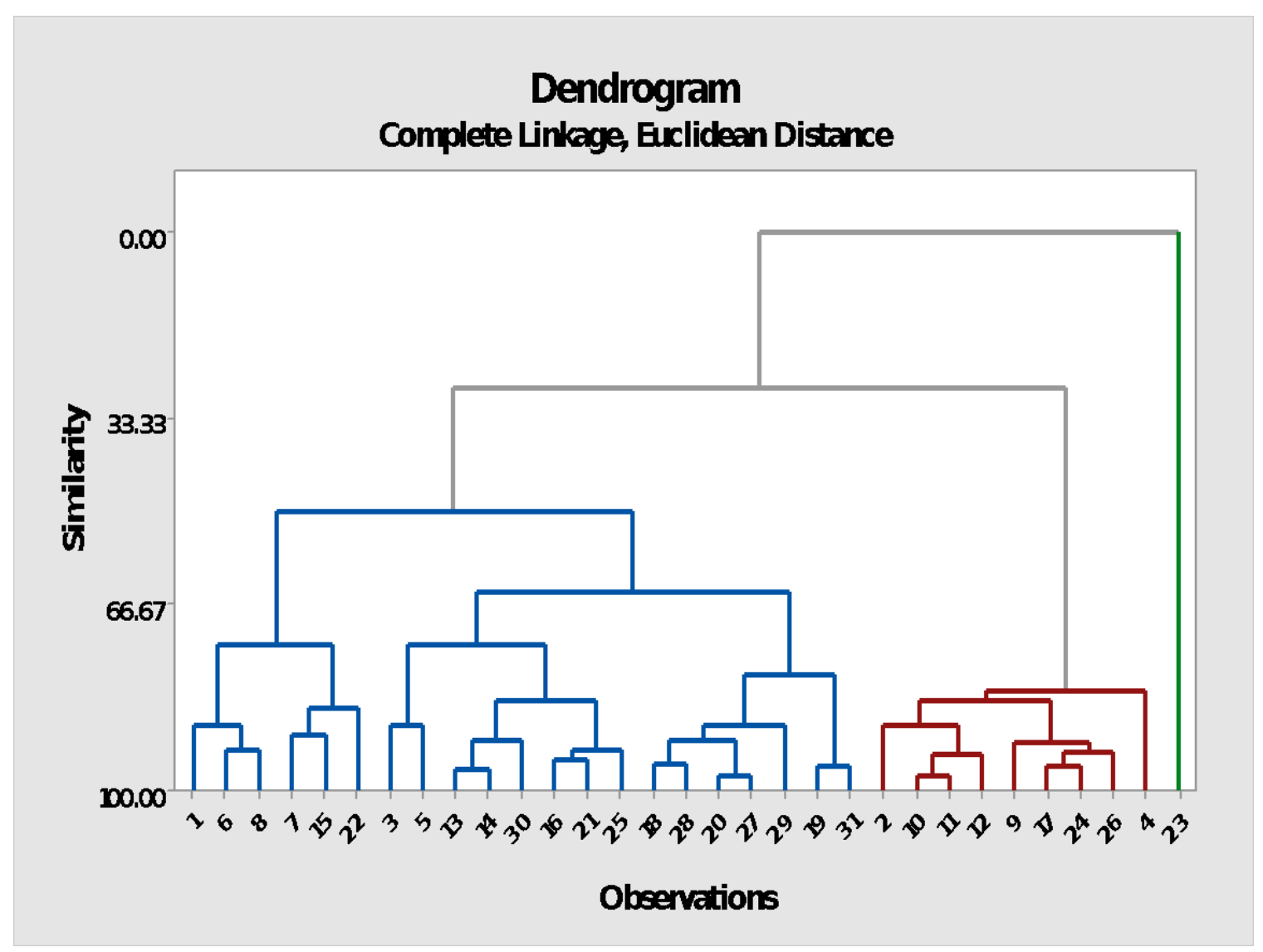

Figure 1: Dendrogram of 31 accessions of Jatropha curcas

The biplot of Principal axes 1 and 2 is presented in Figure 2. It showed that genotypes 30, 28, 27 8 and 23 were the most distinct genotypes as well 
as genotype 1 and 13 . Genotypes 2, 4, 7, 9, 16, 18,21 , and 31 are the least variable.

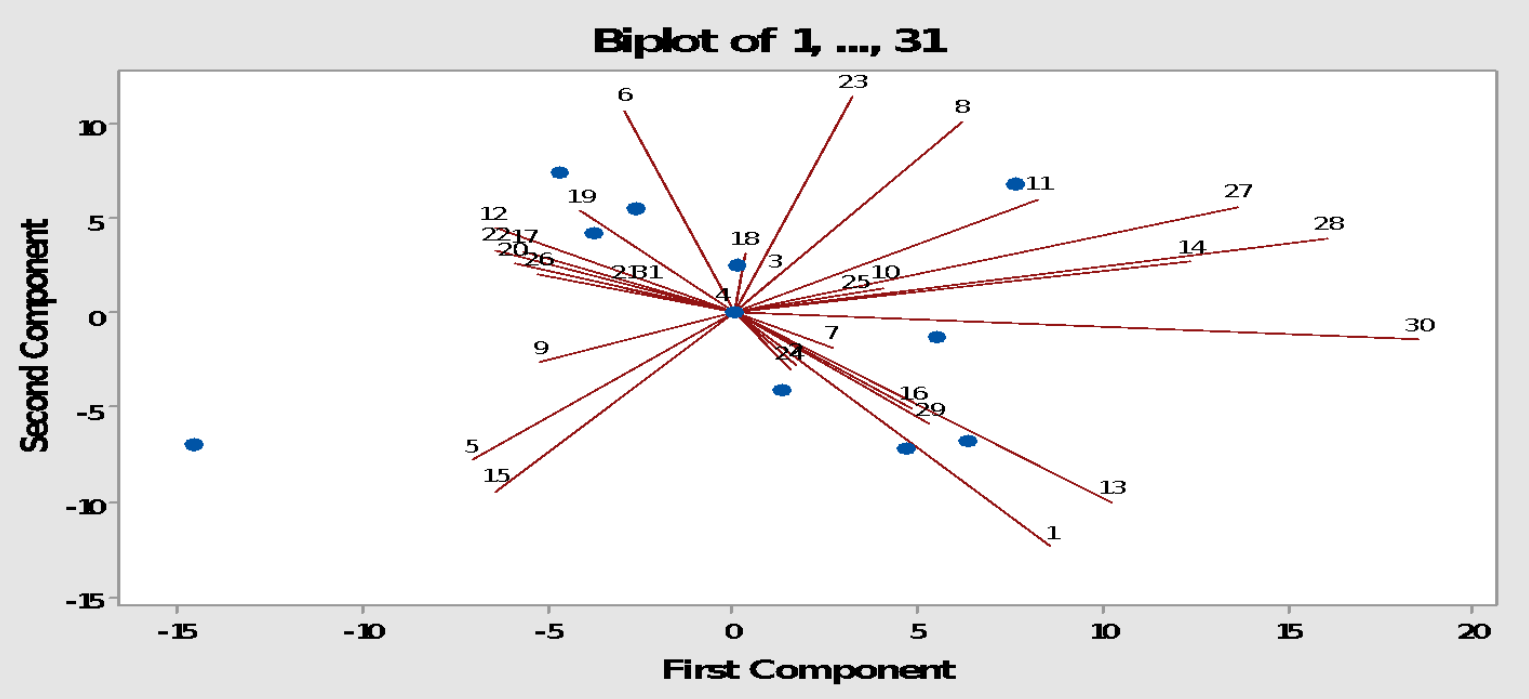

Figure2: Biplot of Principal Component Axes 1 and 2 of 31 Accessions of J. curcas

\section{Discussion}

Genetic diversity is an important factor in plant breeding because it informs the choice of genotypes for selection and providing this in Jatropha breeding for traits improvement is very crucial. There were significant differences observed among the accessions used in this study for all the morphological characters (number of leaves, collar diameter and plant height) examined as this is an indication of broad genetic base in the accessions used. The result from the assessment of these traits from all the accessions under study clearly showed that $7(22.58 \%)$ out of the 31 accessions have their mean greater than the grand mean. 1 from Oyo state, 3 from Osun state, 1 from Ekiti and 2 from Ondo state. This reflects greater adaptability of some J. curcas to agro climatic conditions and further suggests that variability is not related to geographical origin. This shows similarity with the work of Melo et. al., (2007) who reported intraspecific variability in leaves of $J$. curcas

The differences observed were attributed to the differences in the genetic makeup of the 31 accessions used. This diversity observed therefore offers potential for selection among the accessions.

Morphological variations among the genotypes were further evaluated by Principal Component Analysis, the analysis indicated that the overall diversity observed in $J$. curcas could be explained by the first significant three Eigen vectors. Characters like number of leaves as well as plant height were fairly distributed among three axes. Collar diameter was also important to the variations in two out of the three principal components. The differences in the contributions of the characters to the total variation is as a result of genetic differences. According to Cruz et. al., (2012), knowledge on the contribution of characters to the variation observed are important in order to select those characters which best differentiate the accessions and exclude those that do not effectively contribute to genotype discrimination. Many authors have worked on the major role of morphological traits in genetic variation in plant species, such as Irvingia gabonensis (Atangana et al., 2002) and Dacryodes edulis (Alaje et. al., 2018; Waruhiu et al., 2004)

The Dendrogram constructed revealed three distinct clusters of genetic similarities and differences. High genetic similarities were observed among genotypes collected from different States whereas some genotypes collected from similar regions had low genetic similarities. For example, genotypes JAT01 and JAT02 were collected from Oyo state but were genetically dissimilar while genotypes JAT01 and JAT30 that were collected from Oyo state and Ondo state respectively were genetically similar. This pattern of clustering indicated that there was 
no association between eco-geographical distribution of genotypes and genetic diversity as genotypes selected under diverse locations, got clustered together. This indicates that genetic drift produce greater diversity than the geographic diversity (Singh et al., 1996; Selvakumar et al., 1989). This also is in agreement with the study of Josephine et al., 2015, who reports that the genetic diversity detected in Dacryodes edulis was intrapopulation.

The cluster analysis of the 31 genotypes of $\mathrm{J}$. curcas that exhibited three different clusters further confirmed the relationship that existed between characters. The characters contributing to the differences are usually given greater emphasis for deciding the type of clusters. This is mainly for the purpose of further selection and the choice of parent for hybridization (Jagadeb and Semal, 1991).

The significant differences observed within the $J$. curcas accessions used in this study indicated genetic divergence which is useful in breeding superior lines. Cluster analysis of the cluster mean revealed three distinct clusters of J. curcas. Members of cluster 2 have proven to be the superior genotypes in terms of plant height, collar diameter and number of leaves. Seven out of the 31 accessions used have high values for collar diameter, number of leaves and plant height and this offer great potential for selection. There is therefore enormous potential for selection among the genotypes due to their genetic differences.

\section{References}

Achten W, Nielsen L, Aerts R, Lengkeek A, Kjær E, Trabucco A, Hansen J, Maes W, Graudal L, Akinnifesi F. (2010): Towards domestication of Jatropha curcas. Biofuels 1: 91-107

Achten W, Verchot L, Franken YJ, Mathijs E, Singh VP, Aerts R, Muys B. (2008): Jatropha biodiesel production and use. Biomass and Bioenerg 32: 1063-1084

Alaje V.I., Alake C.O., Olalekan O. (2018): GenotypexEnvironment Interaction in Seedling Growth Characteristics of African Pear Fruit (Dacryodes Edulis (G.Don) H.J. Lam) Accessions.
International Journal of Innovative Science and Research Technology. Volume 3, Issue 11 pp227235

Atangana, A.R., Ukafor, V., Anegbeh, P.O., Asaah, E., Tchoundjeu, Z., Usoro, C., Fondoun, J.M., Ndoumbe, M., Leakey, R.R.B. (2002): Domestication of Irvingia gabonensis: 2. The selection of multiple traits for potential cultivars from Cameroon and Nigeria. Agroforest Syst $55: 221-229$

Blench, R. (2003): Hausa names for plants and trees. Available at http://www.org/odi/staff/r. Printout August 5, 2003

Blench, R. (2007): Hausa names for plants and trees. http://www.rogerblench.info/RBOP.htm Cai Y, Sun D, Wu G, Peng J. (2010): ISSR-based genetic diversity of Jatropha curcas germplasm in China. Biomass and Bioenerg 34: 1739-1750

Cruz CD, Regazzi AJ, Carneiro PCS (2012). Modelos Biométricos Aplicados ao Melhoramento Genético- Volume 1. $4^{a}$ edição. EditoraUFV, Viçosa, 514 pp.

Divakara B, Upadhyaya H, Wani S, Gowda C. (2010): Biology and genetic improvement of Jatropha curcas L: a review. Applied Energy 87: 732-742

Fact Foundation. (2006): Hand book on Jatropha Curcas.First Draft. March 2006. Accessed at

http://www.jatropha platform.org/documents/F actfoundation jatropha Handbook March 2006. pdf. $1 / 6 / 2009$

Franco J, Crossa J, Ribaut J, Bertran J, Warburton M, Khairallah M. (2001): A method for combining molecular markers and phenotypic attributes for classifying plant genotypes. Theor App Genet 103: 944-952

Ganesh Ram S, Parthiban K, Senthil Kumar R, Thiruvengadam V, Paramathma M. (2008): Genetic diversity among Jatropha species as revealed by RAPD markers. Genet Resour Crop Ev 55: 803- 809

Ghosh L, Singh L. (2011): Variation in seed and seedling characters of Jatropha curcas $L$ with 
varying zones and provenances. Trop Ecol 52: 113-122

Ginwal H, Phartyal S, Rawat P, Srivastava R. (2005): Seed source variation in morphology, germination and seedling growth of Jatropha curcas L in central India. Silvae Genetica 54: 7679

Gohil R, Pandya J, (2009): Genetic evaluation of Jatropha (Jatropha curcas L) genotypes. J Agric Res 47: 221-228.

Gubitz GM, Mittelbach M and Trabi M. (1999): Exploitation of the tropical oil seed plant Jatropha curcasL.,BioresourceTechnology Vol. 67 pp7382.Fangrui M, Milford A. H. (1999): Biodiesel production: a review. Bioresource Technol 70: 115

Heller J. (1996): Physic Nut. Jatropha curcas L. Promoting the conservation and use of underutilized and neglected crops. 1. Institute of Plant Genetics and Crop Plant Research, Gatersleben/International Plant GeneticResources Institute, Rome. ISBN 929043-278-0.

Jagaded, P.N. and Samal, K.M. 1991. Multivariate analysis in niger (Guizotica abyssinicacass) Indian J. Genet., 30: 767-788.

Jongschaap REE, Corre WJ, Bindraban PS and Brandenburg WA. (2007): Claims and Facts on jatropha curcas L : Global Jatropha curcas evaluation, breeding and propagation Programme. Plant Research International, B.V. Wageningen, The Netherlands. p1-

Josephine, T.M, Gordon, O., Zac T., Alice, M., Alain T., Ebenezer, A. and Robert, K. 2015.

Genetic diversity of Dacryodes edulis provenances used in controlled breeding trials. Journal of Plant Breeding and Crop Science pp3439

Juhász, S. Pimenta, B.O. Soares, Batista Morais de Lourdes, D., Rabello, H. de Oliveira (2009): Floral biology and artificial polinization in physic nut in the north of Minas Gerais state, Brazil [Biologia floral e polinização artificial de pinhãomanso no norte de Minas Gerais] Pesquisa
Agropecuaria Brasileira, 44(9): 1073-1077 (in Portuguese).

Kaushik N, Kumar K, Kumar S, Kaushik N, Roy S. (2007): Genetic variability and divergence studies in seed traits and oil content of Jatropha (Jatropha curcas L.) accessions. Biomass Bioenergy 2007; 31:497-502.

King A, He W, Cuevas J, Freudenberger $M$, Ramiaramanana D, Graham I, (2009): Potential of Jatropha curcas as a source of renewable oil and animal feed. J Exp Bot 60: 2897-2905

Kumar A, Sharma S, (2008): An evaluation of multipurpose oil seed crop for industrial uses (Jatropha curcas L): A review. Industrial crops and products 28: 1-10

Martinez-Herrera J, Siddhuraju P, Francis G, Davila Ortiz G, Becker K. (2006): Chemical composition, toxic/ antimetabolic constituents, and effect of different treatments on their levels, in four provenances Jatropha curcas L. from Mexico. Food Chem., 96: 80-89.

Melo MFV, Silva-Mann R, Santos HO, Souza EM (2007). Caracterização morfológica de acessos de Jatropha curcas $L$. do banco de germoplasma da Universidade Federal de Sergipe. In: Anais do Congresso da Rede Brasileira de Tecnologia de Biodiesel, Brasília (CD Room).

Nahar, K. and Ozores-Hampton, M. (2011). Jatropha: An Alternative Substitute to Fossil Fuel. (IFAS Publication Number HS1193). Gainesville: University of Florida, Institute of Food and Agricultural Sciences. Retrieved (12-17-2011).

Rafii MY, Shabanimofrad M, Puteri Edaroyati MW, Latif MA. (2012a): Analysis of the genetic diversity of physic nut, Jatropha curcas $L$ accessions using RAPD markers. Mol Biol Rep 39: 6505-6511

Rao G, Korwar G, Shanker A, Ramakrishna Y. (2008): Genetic associations, variability and diversity in seed characters, growth, reproductive phenology and yield in Jatropha curcas (L) accessions. 170 Maydica electronic publication, Trees-Struct Funct 22: 697-709

Selvakumar, K.S., Soundrapandian, G., Amirthadevarathinam, A., 1989. Genetic 
divergence for yield and yield components in cold tolerance rice. Madras Agric. J., 76, 688-694.

Shabanimofrad M, Rafii MY, Megat Wahab PE, Biabani AR, Latif MA. (2013): Phenotypic, genotypic and genetic divergence found in 48 newly collected Malaysian accessions of Jatropha curcas L. Ind Crop Prod 42: 543-551

Shabanimofrad M, Yusop MR, Saad MS, Megat PE, Wahab AB, Latif MA. (2011): Diversity of physic nut (Jatropha curcas) in Malaysia: application of DIVA-geographic information system and cluster analysis. Aust J Crop Sci 5: 361-368

Sharama S, Kumar N, Reddy MP. (2011): Regeneration in Jatropha curcas: Factors affecting the efficiency of in vitro regeneration. Ind Crop Prod 34: 943-951

Shuit S, Lee K, Kamaruddin A, Yusup S. (2010): Reactive extraction and in situ esterification of Jatropha curcas $L$ seeds for the production of biodiesel. Fuel 89: 527-530

Singh, A.K., Singh, S.B., and Singh, S.M., 1996. Genetic divergence in scented and fine genotypes of rice (Oryza sativa L.) Ann. Agric. Res., 17, 163166.

Sujatha M, Reddy TP, Mahasi M. (2008): Role of biotechnological interventions in the improvement of castor (Ricinus communis $\mathrm{L}$ ) and Jatropha curcas L. Biotechnology Adv 26: 424435

Sukarin W, Yamada Y, Sakaguchi S. (1987): Characteristics of physic nut, Jatropha curcas $L$ as a new biomass crop in the Tropics. Japanese Agricultural Research Quarterly 20: 302-303

Sun Q, Li L, Li Y, Wu G, Ge X. (2008): SSR and AFLP markers reveal low genetic diversity in the biofuel plant Jatropha curcas in China. Crop Sci 48: 1865-1871171 Maydica electronic publication $-2012$ 